\title{
Parasitological diagnosis in food fish produced in a fish farm, in the Zona da Mata, Minas Gerais, southeastern Brazil
}

\author{
Diagnóstico parasitológico em peixes para consumo produzidos em uma \\ psicultura, na Zona da Mata, Minas Gerais, região sudeste do Brasil
}

Rachel Sordi Relvas'; Simone de Carvalho Balian'; Herbert Sousa Soares ${ }^{1,2}$; Maurício Laterça Martins ${ }^{3}$; Pedro Henrique Magalhães Cardoso ${ }^{1 *}$ (1)

\footnotetext{
${ }^{1}$ Departamento de Medicina Veterinária Preventiva, Faculdade de Medicina Veterinária e Zootecnia, Universidade de São Paulo - USP, São Paulo, SP, Brasil

${ }^{2}$ Programa de Pós-graduação em Medicina Veterinária e Bem Estar Animal e Saúde Única, Universidade Santo Amaro - UNISA, São Paulo, SP, Brasil

${ }^{3}$ Laboratório de Sanidade de Organismos Aquáticos - AQUOS, Departamento de Aquicultura, Universidade Federal de Santa Catarina UFSC, Florianópolis, SC, Brasil
}

How to cite: Relvas RS, Balian SC, Soares HS, Martins ML, Cardoso PHM. Parasitological diagnosis in food fish produced in a fish farm, in the Zona da Mata, Minas Gerais, southeastern Brazil. Braz J Vet Parasito/ 2020; 29(4): e019520. https://doi.org/10.1590/ S1984-29612020100

\begin{abstract}
This study identified the parasitic species in juvenile freshwater finfishes during the fattening stage, from a fish farm located in the Zona da Mata (MG), southeastern Brazil, and revealed both macro and microscopical lesions in fish gills. A total of 172 juvenile fishes of different species (Oreochromis niloticus, Ictalurus punctatus, Ctenopharyngodon idella, Cyprinus carpio, Astyanax bimaculatus and Brycon amazonicus) were transported to a laboratory in São Paulo city. The fish were sedated and then euthanized for parasitological analysis. All fish were infected by at least one parasite species. Ten different species of parasites were identified: Apiosoma sp., Epistylis sp., Ichthyobodo sp., trichodinids, Piscinoodinium pillulare, Ichthyophthirius multifiliis, Tetrahymena sp., monogeneans, Centrocestus formosanus metacercariae, and Dermocystidium sp. The best management practices and lack of sanitary control were also discussed.
\end{abstract}

Keywords: Aquatic health, parasitic disease, cultured fish.

\section{Resumo}

Este trabalho identificou espécies parasitas em peixes de produção juvenis de água doce, durante a fase de engorda, oriundos de uma piscicultura da Zona da Mata (MG), na região sudeste do Brasil, além das lesões de brânquias, causadas tanto macro quanto microscopicamente. Um total de 172 peixes juvenis de diferentes espécies (Oreochromis niloticus, Ictalurus punctatus, Ctenopharyngodon idella, Cyprinus carpio, Astyanax bimaculatus e Brycon amazonicus) foram transportados para um laboratório na cidade de São Paulo. Os peixes foram anestesiados e eutanasiados para análise parasitológica. Todos os peixes estavam acometidos por pelo menos uma espécie de parasito. Dez diferentes espécies de parasitos foram identificadas: Apiosoma sp., Epistylis sp., Ichthyobodo sp., tricodinídeos, Piscinoodinium pillulare, Ichthyophthirius multifiliis, Tetrahymena sp., monogeneas, metacercárias de Centrocestus formosanus e Dermocystidium sp. As boas práticas de manejo e inadequado controle sanitário também foram discutidos.

Palavras-chave: Sanidade aquícola, doença parasitária, peixe cultivado. 


\section{Introduction}

Despite capture fisheries production being static since the 1980s, overall fish production has continued to grow because of aquaculture. In 2016, aquaculture comprised $46.8 \%$ of global fish production, producing 80 million tons worth US $\$ 231.6$ billion $(F A O, 2018)$. In the same year, Brazil represented the $13^{\text {th }}$ largest aquaculture producer, with 640,510 tons of fish produced (Baptista et al., 2018; FAO, 2018), and in 2019, the amount increased to 758,006 tons (Carvalho et al., 2020).

In contrast to other animal protein production activities, aquaculture displays significantly superior growth both globally and in Brazil (Schulter \& Vieira, 2017; FAO, 2018). A factor contributing to this expansion is the high productivity per hectare (60 times higher than beef cattle production) as a result of intensive aquaculture system (Schulter \& Vieira, 2017). However, some issues emerge easily along with this system, such as appropriate management, water quality, biosecurity, and disease and parasite control (El-Sayed, 2006).

The intensive system modifies the host-parasite-environment relationship and frequently leads to stressful conditions, which immunosuppress individuals. Hence, fish become more susceptible to parasitic infections (as a result of an immunological imbalance) that may cause considerable mortalities, especially if there is a secondary bacterial or viral infection (Noga, 2010; Jerônimo et al., 2012). Ectoparasite communities such as protozoans, monogeneans, digenean larvae and crustaceans (Jerônimo et al., 2015) present in cultured fish in the facilities could be used as bioindicator of environmental and fish health status (Antonelli et al., 2016; Lacerda et al., 2018) in order to improve and implement the best management practices.

Knowledge of parasitic infections helps to minimize economic losses and promotes the development and growth of aquaculture activity. Farms destined to fish production for human consumption have received attention of Brazilian researchers in the recent years. Farmers faced with these problems should be encouraged to minimize economic losses in applying the correct fish handling management including the parasitic diagnosis in culture fish. Thus, the aim of this study was to identify the ectoparasites in different juvenile freshwater finfishes during fattening, from a fish farm in the Zona da Mata, Minas Gerais State, southeastern Brazil and to verify if there was adequate water quality and biosecurity practices at the farm.

\section{Material and Methods}

\section{Fish and property conditions}

From December 2018-May 2019, 172 juvenile fishes of six species were collected from a fish farm in the Zona da Mata, Minas Gerais, Brazil (the research project was approved by the Animal Use Ethics Committee of FMVZ-USP 1976201218). The number of fish sampled from each species was 72 Nile tilapia, Oreochromis niloticus (1.6 $\pm 2.4 \mathrm{~g}$ and $4.4 \pm 1.5 \mathrm{~cm}$ long), 23 channel catfish, Ictalurus punctatus ( $1.1 \pm 0.5 \mathrm{~g}$ and $5.2 \pm 0.8 \mathrm{~cm}$ long), 22 grass carp, Ctenopharyngodon idella (1.8 $\pm 1.1 \mathrm{~g}$ and $5.2 \pm 1.3 \mathrm{~cm}$ long), 19 common carp, Cyprinus carpio (0.4 $\pm 0.6 \mathrm{~g}$ and $2.6 \pm 0.4 \mathrm{~cm}$ long), 19 two-spot astynax, Astyanax bimaculatus $(0.9 \pm 0.6 \mathrm{~g}$ and $4.0 \pm 0.7 \mathrm{~cm}$ long), and $17 \mathrm{red}-$ tailed brycon, Brycon amazonicus ( $1.3 \pm 0.5 \mathrm{~g}$ and $4.6 \pm 0.5 \mathrm{~cm}$ long).

Farmer used river nearby for water supply to the ponds (dimensions of 20:10:1 meters) without any treatment, neither parasite nor water quality measure. Moreover, no mechanical aerators and the eutrophication of the water were common. Fish were stocked at $3.000 \mathrm{fish} / \mathrm{m}^{3}$, considered a high stocking density. There was not a fallowing routine before the introduction of new fish populations.

\section{Sample collection}

The fish were transported in plastic bags to São Paulo city, southeastern Brazil. Then, they were identified by species, weight, and total length. The total length is defined as the distance from the mouth to the end of the tail (Jerônimo et al., 2012). The fish were quickly sedated by adding Eugenol (75 mg L-1 of eugenol) for $3 \mathrm{~min}$ (Roubach et al., 2005), and euthanized by brain section (Noga, 2010).

\section{Sample analysis}

The parasites were identified based on their structure, morphology and movement pattern (Woo, 2006; Zhang \& Wang, 2005; Noga, 2010; Klinger \& Floyd, 2013; Martins et al., 2015; Fujimoto et al., 2018; Sumuduni et al., 2018). Gills identified, under wet mount procedure (described above), with more than forty encapsulated metacercariae (in C. carpio, I. punctatus and B. amazonicus) were selected, fixed with $10 \%$ neutral buffered formalin, and subjected to histology; samples from animals manifesting cysts were also subjected to histology (Mumford et al., 2007). 
Prevalence, mean intensity and mean abundance were calculated with the data collected, in accordance with Rózsa et al. (2000).

\section{Water quality and biosecurity practices evaluation}

During technical visits at the farm, the water quality and biosecurity practices were verified through the presence or absence of methods for diseases and parasites prevention (filters, biofilters, and UV radiation devices) staff routines towards fish care, feeding practices, fallowing and quarantine routines, equipment to control water quality (mechanical aerators), and water quality testing routines (such as measurement of $\mathrm{pH}$, ammonia and dissolved oxygen). Besides, it was evaluated whether there was or not contact with wild animals (birds, for example).

\section{Results}

Through wet mount observations, it was detected that $100 \%$ of the animals were infected by at least one parasite: $1.2 \%$ (2/172) of the fish had a parasite only on the skin; $27.33 \%$ (47/172) had only on the gills; and $71.5 \%(123 / 172)$ had parasites on both. The parasites detected were Apiosoma sp. (Figure 1A), Ichthyobodo sp., trichodinids (Figure 1B), Ichthyophthirius multifiliis (Figure 1C), Piscinoodinium pillulare (Figure 1D), Tetrahymena sp. (Figure 1E), Epistylis sp. (Figure 1F), monogeneans (Figure 1G), Centrocestus formosanus metacercariae (Figure 1H), and Dermocystidium sp. (Figure 1I). The prevalence, mean intensity, and mean abundance of each parasite on the different species can be observed in Table 1.

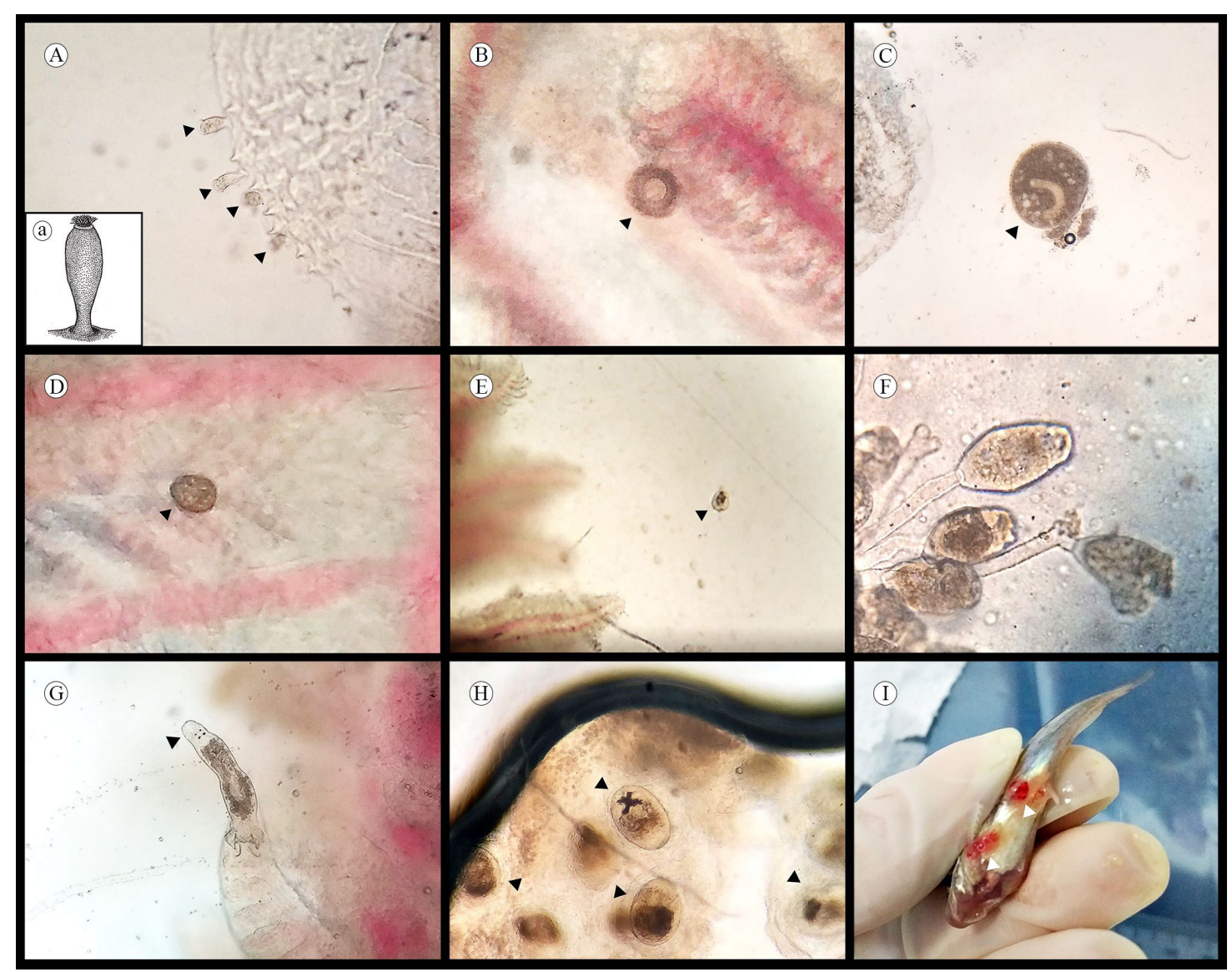

Figure 1. (A) Apiosoma sp. on a scale from Oreochromis niloticus on a wet mount of the skin (20x magnification); a: a diagram of Apiosoma (Noga, 2010); (B) wet mount of a Trichodinid parasite on gills from O. niloticus (40x magnification); (C) Ichthyophthirius multifiliis on a wet mount of skin from C. idella (4x magnification); (D) Piscinoodinium pillulare on a wet mount of gills from Brycon amazonicus (40x magnification); (E) Tetrahymena sp. on a wet mount of gills from Brycon amazonicus (10x magnification); (F) Epistylis sp. on a wet mount of skin from Ctenopharyngodon idella (20x magnification); (G) monogenean attached to a gill from I. punctatus on a wet mount (20x magnification); $(\mathrm{H})$ metacercariae of Centrocestus formosanus on a wet mount of gills from Cyprinus carpio (20x magnification); (I) cysts of Dermocystidium sp. on skin of Ictalurus punctatus; the parasite can be noticed inside the cysts (arrows). 
As shown in Table 1, different species were infected by different parasites. Also, the most predominant and with the highest intensity infections were of $C$. formosanus and trichodinids. The only species not infected by trichodinids was $A$. bimaculatus. Moreover, except for 0 . niloticus, their intensity was somewhat low in other species. However, some O. niloticus individuals had over 4,000 parasites (Figure 2B).

Dermocystidium cysts, were found solely on I. punctatus. Histology of these fish showed, between dermis and epidermis, cysts full of spores and encapsulated by connective tissue. In contrast, C. formosanus metacercariae were identified in every species analyzed. The number of metacercariae was so high in some animals that the gills became deeply disfigured (Figure 2C). For example, in a few I. punctatus over 1,400 were present. Furthermore,

Table 1. Parasitological indicator of protozoans, metazoans and Dermocystidium sp. from each species analyzed and from fishes as a whole.

\begin{tabular}{|c|c|c|c|c|c|c|c|c|}
\hline \multirow{2}{*}{ Parasites } & \multirow{2}{*}{ PI } & \multicolumn{7}{|c|}{ Fish species } \\
\hline & & O. niloticus & C. carpio & I. punctatus & B. amazonicus & C. idella & A. bimaculatus & All fishes \\
\hline \multirow[t]{3}{*}{ Api. } & $\mathrm{P}$ & 0.24 & - & - & - & 0.05 & 0.11 & 0.12 \\
\hline & $\mathrm{Ml}$ & $14.47(1-50)$ & - & - & - & $1.00(1)$ & $1.50(1-2)$ & $12.50(1-50)$ \\
\hline & MA & 3.42 & - & - & - & 0.05 & 0.16 & 1.45 \\
\hline \multirow[t]{3}{*}{ Epi. } & $\mathrm{P}$ & 0.01 & - & - & - & 0.18 & - & 0.03 \\
\hline & $\mathrm{Ml}$ & $1.00(1)$ & - & - & - & $4.50(1-7)$ & - & $3.80(1-7)$ \\
\hline & MA & 0.01 & - & - & - & 0.82 & - & 0.11 \\
\hline \multirow[t]{3}{*}{ lbd. } & $\mathrm{P}$ & 0.07 & - & - & - & - & 0.16 & 0.05 \\
\hline & $\mathrm{Ml}$ & $1.60(1-3)$ & - & - & - & - & $15.00(10-20)$ & $6.63(1-20)$ \\
\hline & MA & 0.11 & - & - & - & - & 2.37 & 0.31 \\
\hline \multirow[t]{3}{*}{ Tri. } & $\mathrm{P}$ & 0.99 & 0.74 & 0.57 & 0.53 & 0.50 & - & 0.69 \\
\hline & $\mathrm{Ml}$ & $543.54(1-4840)$ & $4.64(1-5)$ & $13.85(3-20)$ & $2.67(1-10)$ & $6.73(1-40)$ & - & $329.95(1-4840)$ \\
\hline & MA & 535.99 & 3.42 & 7.83 & 1.41 & 3.36 & - & 226.36 \\
\hline \multirow[t]{3}{*}{ Pis. } & $\mathrm{P}$ & 0.17 & - & 0.35 & 0.59 & 0.77 & 0.74 & 0.35 \\
\hline & $\mathrm{Ml}$ & $10.17(1-82)$ & - & $3.38(1-6)$ & $23.70(1-96)$ & $4.94(1-11)$ & $4.14(1-9)$ & $8.66(1-96)$ \\
\hline & MA & 1.69 & - & 1.17 & 13.94 & 3.82 & 3.05 & 3.07 \\
\hline \multirow[t]{3}{*}{ Ich. } & $\mathrm{P}$ & 0.04 & - & 0.09 & 0.47 & 0.45 & 0.05 & 0.14 \\
\hline & $\mathrm{Ml}$ & $2.33(1-4)$ & - & $1.00(1)$ & $11.13(1-33)$ & $3.60(1-10)$ & $2.00(2)$ & $5.67(1-33)$ \\
\hline & MA & 0.10 & - & 0.09 & 5.24 & 1.64 & 0.11 & 0.79 \\
\hline \multirow[t]{3}{*}{ Tet. } & $\mathrm{P}$ & 0.01 & - & 0.22 & 0.24 & - & 0.11 & 0.07 \\
\hline & $\mathrm{Ml}$ & $2.00(2)$ & - & $1.40(1-3)$ & $8.50(1-19)$ & - & $2.00(2)$ & $3.92(1-19)$ \\
\hline & MA & 0.03 & - & 0.30 & 2.00 & - & 0.21 & 0.27 \\
\hline \multirow[t]{3}{*}{ Mon. } & $\mathrm{P}$ & 0.78 & - & 0.65 & 0.24 & 0.27 & 0.68 & 0.55 \\
\hline & $\mathrm{Ml}$ & $6.27(1-37)$ & - & $11.47(10-20)$ & $7.50(1-20)$ & $1.50(1-2)$ & $6.92(1-16)$ & $6.94(1-37)$ \\
\hline & MA & 4.88 & - & 7.48 & 1.76 & 0.41 & 4.74 & 3.79 \\
\hline \multirow[t]{3}{*}{ Cen. } & $\mathrm{P}$ & 0.17 & 1.00 & 1.00 & 1.00 & 0.95 & 0.79 & 0.62 \\
\hline & $\mathrm{Ml}$ & $2.08(1-4)$ & $250.95(176-384)$ & $530.57(41-1440)$ & $63.29(1-400)$ & $93.67(5-240)$ & $5.73(1-22)$ & $188.08(1-1440)$ \\
\hline & MA & 0.35 & 250.95 & 530.57 & 63.29 & 89.41 & .53 & 117.01 \\
\hline \multirow[t]{3}{*}{ Der. } & $\mathrm{P}$ & - & - & 0.35 & - & - & - & 0.05 \\
\hline & $\mathrm{Ml}$ & - & - & $3(1-5)$ & - & - & - & $3(1-5)$ \\
\hline & MA & - & - & 1.04 & - & - & - & 0.14 \\
\hline
\end{tabular}

Api.: Apiosoma sp.; Epi.: Epistylis sp.; Ibd.: Ichthyobodo sp.; Tri.: Trichodinids; Pis.: Piscinoodinium pillulare; Ich.: Ichthyophthirius multifiliis; Tet.: Tetrahymena sp. Mon.: Monogeneans; Cen.: Centrocestus formosanus; Der.: Dermocystidium sp. PI: parasitological indices; P: prevalence; MI: mean intensity; MA: mean abundance; In parentheses: variation amplitude. 


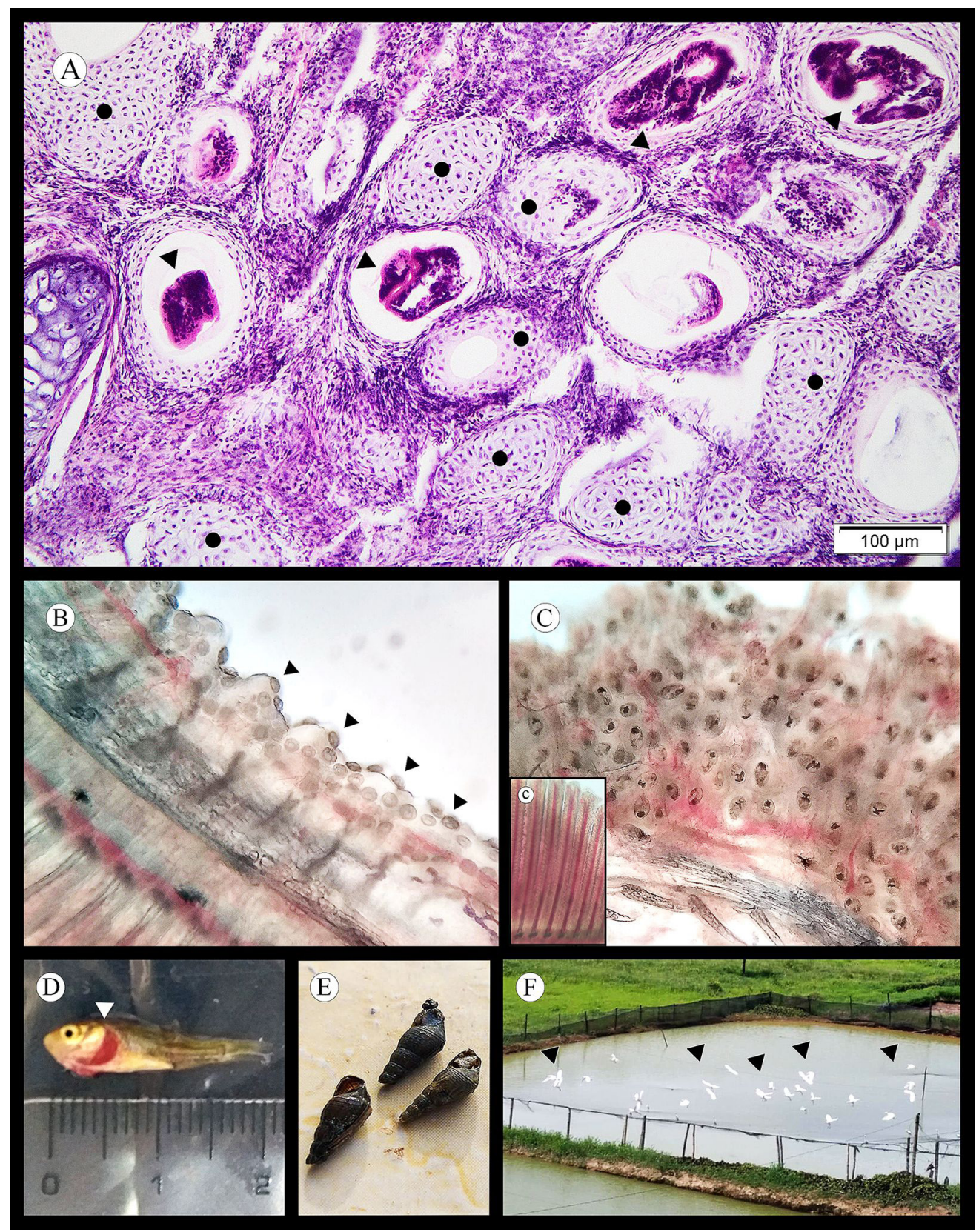

Figure 2. (A) Histology of the gill from Cyprinus carpio stained with hematoxylin and eosin. Notice the cartilaginous capsule (circles) around Centrocestus formosanus (arrows); (B) Wet mount with a high number of trichodinids on a gill from Oreochromis niloticus (10x magnification); (C) Wet mount with a great number of metacercariae of Centrocestus formosanus in a gill from Ictalurus punctatus (4x magnification); the structure of gill filaments is severely damaged; c: normal gill filaments from O. niloticus; (D) Cyprinus carpio with the opercula flared out and gills visible; (E) Snails discovered in the farm fish; (F) Birds in close contact with an eutrophicated fish tank.

there was hypertrophy in the gills of these fish, flaring out their opercula (notably in C. carpio) and, consequently, making the gills visible on a macroscopic level (Figure 2D). Histology of these gills revealed an intense proliferation of cartilage tissue, forming a cartilaginous capsule around the parasite (Figure 2A). It is important to highlight that, at the farm, the fish were in close contact with snails and birds (Figures 2E and 2F). The morphology of the snail shells was indicative of the species Melanoides tuberculatus, which is the intermediate host of this parasite, and the birds are the definitive hosts.

It was also noticed the farm using a nearby river as water supply without treatment (neither for parasite control nor for water quality), the absence of mechanical aerators the presence of food on water surface, and presence of eutrophication [excess of organic matter and algae] (Figure 2F). The fish farm used wheat bran and urea as fertilizers 
to increase plankton and algae populations (which are also nutrition supplies for fish). The water quality control composed of a monthly $\mathrm{pH}$ measurement, and supplementing water with calcium carbonate $\left(\mathrm{CaCO}_{3}\right)$, when $\mathrm{pH}$ levels were low (three to five supplementations per year). However, there was no evaluation of neither ammonia nor dissolved oxygen. Before the introduction of new fish populations, a fallowing routine was not implemented. Besides, the property produced both food and ornamental fish, and management practices were realized by the same staff members.

\section{Discussion}

The protozoans Apiosoma, Epistylis, trichodinids, Ichthyobodo, and Tetrahymena are commonly found in high stocking densities (El-Sayed, 2006). In our study, of these five protozoans, only one was identified in C. carpio (trichodinids). In contrast, $O$. niloticus was infected by all five of them. I. punctatus and B. amazonicus were infected by trichodinids and Tetrahymena sp.; C. idella by Epistylis sp. and trichodinids; and A. bimaculatus by Apiosoma sp., Ichthyobodo sp., and Tetrahymena sp.

Apiosoma, Epistylis, and trichodinids are considered to be commensals, feeding on waterborne particles, detritus particles, and bacteria (Woo, 2006; Noga, 2010; Martins et al., 2015). Thus, they are good indicators of poor water quality (indicating abundance of organic particles) and never occur in great numbers on healthy fish. However, trichodinids are associated with chronic mortality and sometimes provoke significant losses in young fish (Woo, 2006; Noga, 2010; Maciel et al., 2018). In high numbers, their constant attachment and movement may evoke severe tissue damage, and open doors to bacterial and fungal infections (El-Sayed, 2006; Woo, 2006; Maciel et al., 2018). Epistylis is also associated with a bacterial infection known as red-sore disease, which causes skin ulcers (Woo, 2006; Noga, 2010). Pádua et al. (2016) discovered bacterial microbiota associated with the peduncle of Epistylis sp. in Nile tilapia and hybrid surubim catfish (Pseudoplatystoma reticulatum $\times$ P. corruscans), leading to focal hyperplasia, hydropic degeneration, and multifocal necrosis. With respect to the great number of tricodinids, our study corroborates other authors' findings. Ghiraldelli et al. (2006) reported infections with a mean intensity of 2,155 and a maximum number of 6,258 trichodinids (higher than found through this research), also in O. niloticus. Valladão et al. (2016) also detected parasitism by trichodinids with other endemic parasites in O. niloticus, reaching 1,097 $\pm 1,080.60$ trichodinids per fish on skin and 1,132.6 \pm 949.7 on gills.

Ichthyobodo is a genus of dinoflagellate protozoans of the skin and gills. Usually, in low numbers, they do not cause clinical signs, or significant mortalities (Martins et al., 2015; Hereford et al., 2019). They have more importance to alevins, juvenile fishes, and even to eggs. In adults, Ichthyobodo infection is associated with immunosuppression and stress. Higher temperatures accelerate their reproduction; thus, heat stress contributes to both stress and debility, and more Ichthyobodo in water (Woo, 2006; Hereford et al., 2019). There are reports of O. niloticus being more resistant to these ectoparasites and only being infected in the caudal region (Woo, 2006). In our study, this parasite was only detected in A. bimaculatus and O. niloticus.

Despite the majority of species from the Tetrahymena genus being free-living protozoans and facultative parasites, some of them are obligate parasites (Woo, 2006; Noga, 2010). They can infect a broad variety of hosts, both vertebrate (fish) and invertebrate, such as bivalve mollusks and planarians (Prosser et al., 2018; Rataj \& Vdacny, 2020). They are associated with an excess of organic particles in water (poor water quality) and, when found in numbers lower than five, are not significant (Klinger \& Floyd, 2013). Of all species analyzed in our study, only B. amazonicus presented numbers higher than five (varying from 1-19). Usually, these parasites reside on the skin and gills, yet they can penetrate muscles, eyes, nerves, and internal organs (e.g., the brain and kidneys), leading to severe mortalities. Once installed systemically, there is no treatment (Ferguson et al., 1986; Noga, 2010; Martins et al., 2015). Even though they are generally correlated with ornamental fishes, they can also infect food fishes. For example, in northern Brazil, there is a record of them infecting, for the first time, Colossoma macropomum and tambatinga, hybrids of C. macropomum and Piaractus brachypomus (Grigório, 2013).

Differently from the parasites above, $P$. pillulare and I. multifiliis (commonly known as ich) have a three-stage cycle (one on the host and two in the environment): trophont, the adult and parasitic stage (living on the skin and gills of the host); tomont, the sessile dividing stage; and theront (I. multifiliis) or dinospore ( $P$. pillulare), the mobile infective stage (Noga, 2010; Martins et al., 2015). Temperature influences their cycle immensely; the higher the temperature, the faster the cycle. Outbreaks are usually related to high stocking densities or stress. In addition to thermal stress, other stress factors that may encourage higher numbers of these parasites are low dissolved oxygen, chemical pollutants, and spawning activities (Woo, 2006; Noga, 2010; Martins et al., 2015; Baia et al., 2019). 
Ichthyophthirius multifiliis is considered one of the most important fish parasites in the world (Martins et al., 2015). White nodules appear over the skin of fish infected by this ectoparasite; hence, the name given to the infection (white spot disease). At high infection rates, both parasites provoke skin ulcers, necrosis, and degeneration of gills; however, lesions caused by P. pillulare are frequently more moderate (El-Sayed, 2006; Noga, 2010; Martins et al., 2015; Wang et al., 2019). There are two described species of Piscinoodinium: P. pillulare (from Europe) and P. limneticum (from North America). There are no findings yet of the latter in Brazil (Eiras et al., 2012; Jerônimo et al., 2015). Among the species analyzed, the only one not infected by these two protozoans was C. carpio.

Dermocystidium belongs to a unique class of organisms, the Mesomycetozoea, which stands between the protozoan and metazoan boundary. Despite being classified as protists, they carry features from both Protista and Fungi kingdoms (Mendoza et al., 2002). Infected fish brandish external cysts (spherical sporangia) on their skin, gills, eyes, or internal organs (systemic infections are less frequent) (Eiras \& Silva-Souza, 2000; Mendoza et al., 2002; Zhang \& Wang, 2005; Mahboub \& Shaheen, 2020). Zhang \& Wang (2005) reported findings of juvenile fishes being more susceptible, and a correlation existing between infections of Dermocystidium and thermal stress in Silurus meridionalis catfish. Mahboub \& Shaheen (2020) also reported the highest infection rates in winter, in O. niloticus. There are only three reports of this parasite in Brazil. The first was in wild catfish (Trichomycterus sp.) (Eiras \& Silva-Souza, 2000), the second was in tambatingas (Fujimoto et al., 2018), and the third in O. niloticus, within the last year (Steckert et al., 2019). The histologic and clinical signs from I. punctatus analyzed in our study suggest a Dermocystidium sp. infection. Thus, this is the first article reporting I. punctatus infected with Dermocystidium sp. in Brazil.

On the contrary, monogeneans (plathelminths) are widely dispersed throughout the country (Kohn \& Cohen, 1998). They have high host-specificity and most those whose hosts are fish belong to Dactylogyridae or Gyrodactylidae families (Woo, 2006; Noga, 2010). There are reports of C. carpio and C. idella suffering infections of many different species (Woo, 2006). Besides, Benovics et al. (2018) suggested an influence of the geographic distribution range of host species on monogenean diversity (hosts with wider distributions are exposed to more monogenean species, and thus, hold more diversity). However, in our study, C. carpio was not infected by monogeneans and the intensity of $C$. idella was low. Monogeneans feed on host blood, resulting in a decrease of erythrocytes, hematocrit, and hemoglobin (Restiannasab et al., 2016). Large numbers of monogeneans do not occur in healthy fish, solely in immunosuppressed animals. Therefore, an elevated quantity indicates low water quality, poor sanitary conditions, high stocking density, thermal stress, and an overall stressful environment (Chen et al., 2020), corroborating our findings at the studied fish farm.

Lastly, C. formosanus, a digenean trematode, is highly important for culture systems in the open air, accessible to birds and snails. This parasite needs three different hosts to complete its cycle: the snail $M$. tuberculatus as first intermediate host $(\mathrm{IH})$; a fish as second $\mathrm{IH}$ (the metacercariae stage in gills); and a bird as definitive host (DH) (the adult stage lives in the intestine). This trematode has host-specificity only for the $1^{\text {st }} \mathrm{IH}$ (Scholz \& SalgadoMaldonado, 2000; Noga, 2010). However, it has been reported the snails Semisulcospira libertine (in Taiwan) and Stenomelania newcombi (in Hawaii) also acting as $1^{\text {st }} \mathrm{IH}$ (Chai \& Jung, 2017). The DH can sometimes be another fish, or a mammal (including humans) (De \& Le, 2011; Chai et al., 2013; Chai \& Jung, 2017). All three hosts (snails, fish, and birds) were present at the fish farm analyzed, allowing the cycle to be completed. By causing severe damage to gills, metacercariae may induce significant mortality rates, especially in juvenile fish (Woo, 2006; Noga, 2010). There is a reactive chondroplasia on the primary lamellae of the gill, which becomes thickened; then, it evolves into a fusion of filaments and, consequently, into a distortion of gill morphology (Scholz \& Salgado-Maldonado, 2000; Woo, 2006; Mumford et al., 2007; Noga, 2010; Sumuduni et al., 2018; Leibowitz et al., 2019). Sometimes, the hyperplasia also flares out the opercula, and the gill damage may be visible by gross examination (Sumuduni et al., 2018; Leibowitz et al., 2019). The hypertrophied cartilage forming a cartilaginous capsule around the parasite is pathognomonic for $C$. formosanus (Noga, 2010). These descriptions corroborate the macro and microscopic findings of our study and confirm the $C$. formosanus infections in all species studied: O. niloticus, C. carpio, I. punctatus, B. amazonicus, C. idella, and A. bimaculatus.

The fish farmer reported higher mortality of $C$. carpio some days after their introduction in the tanks, compared to other species. This could be related to the fact that $C$. carpio had the most notable flared out opercula. The farmer also mentioned lower mortality when it was adopted, in some tanks, liming and cleaning practices (removal of water and organic matter of the bottom). The latter circumstance could suggest this low productivity and high mortality as a repercussion of inadequacy in proper sanitary management and biosecurity measures. 
Moreover, there are other studies with similar (and higher) intensities and ranges of infection. In Mexico, Scholz \& Salgado-Maldonado (2000) detected several species from different localities with mean intensities close to, or higher than, 1,000 parasites (one of the species, Gobiomorus maculatus, reached 5,935 metacercariae). M. tuberculatus, an exotic snail from Asia, was introduced to Brazil in the 1960s (Vaz et al., 1986), and to Minas Gerais in the 1980s (Carvalho, 1986). However, only in 2010, in Minas Gerais, the snail was identified with cercariae of C. formosanus (the first report of it in Brazil) (Pinto \& Melo, 2010).

It is important to highlight that the fish analyzed in this study would be destined for human consumption, and that $C$. formosanus has zoonotic potential. Despite the probability of human infection being small (Scholz \& Salgado-Maldonado, 2000), there are some conditions and factors that could increase these chances. Although C. formosanus metacercariae are located predominantly in gills, when highly concentrated, they may also settle on the body, fin, and head regions (Sumuduni et al., 2017). Besides, in Brazil, primarily on the coast and near some rivers, some small fishes are fried and eaten whole (head and gills, inclusive). The metacercariae could still be alive if the fish were undercooked (due to inadequate temperature or cooking time). There is little research about clinical signs and prevalence in humans and the few studies that exist are from Asia. In these studies, patients used to eat raw or undercooked freshwater fish and were concomitantly infected by more than one trematode. They expressed epigastric pain, diarrhea, and indigestion; however, these symptoms cannot be correlated solely with C. formosanus, as patients were also infected with other trematodes (De \& Le, 2011; Chai et al., 2013). Therefore, to prevent human infections, $M$. tuberculatus snails must be eliminated from fish farms, and fish contact with birds must be obstructed (Scholz \& Salgado-Maldonado, 2000; Woo, 2006; Noga, 2010), condition not adopted by the farm.

To prevent all these parasites, it is important to reduce or eliminate predisposing factors. Stocking density must be at appropriate levels for each species. Low water-quality is related to low dissolved oxygen levels, excess of organic particles and ammonia, and misbalanced $\mathrm{pH}$ levels. Mechanical aerators, which were nonexistent in the analyzed farm, add extra dissolved oxygen and maintain it at ideal levels. The excess of organic particles (eutrophication), detected in the farm, is a consequence of improper feeding, which also leads to misbalanced $\mathrm{pH}$ and ammonia. Thus, good feeding management (proper frequency, quantity, and quality) is crucial for good water quality (Noga, 2010; Angel et al., 2019), condition not adopted by the farmer, who did not test for water quality; also, during technical visits of the research, food was observed on the water surface. Although thermal stress contributes to immunosuppression, temperature control is impractical in large volumes of water (Noga, 2010). The water supply must be treated (a missing activity in the farm) to control for parasites and water quality before entering fish tanks. Some treatments include mechanical filters, biofilters, and UV radiation devices (Angel et al., 2019). Moreover, good biosecurity will reduce the transmission of parasites inside, and between properties. Some essential biosecurity activities include equipment disinfection, fallowing, quarantine of new animals, antisepsis of hands from staff members, and control of visiting people and vehicles (Pádua et al., 2012; OIE, 2019). A fallowing routine is essential to discontinue reinfection cycles. It consists of emptying the system of water (when feasible) and of all animals (including vectors) for a certain period before the introduction of a new fish population. During the period, the farm must also clear and disinfect the system (OIE, 2019). The encountered conditions at the farm emphasize a default for water quality and biosecurity (presence of snails and birds, absence of mechanical aerators and water supply treatment, eutrophication and lack of a fallowing routine), leading to the detected number and variety of parasites.

\section{Conclusions}

Every identified parasite (Apiosoma sp., Ichthyobodo sp., trichodinids, I. multifiliis, P. pillulare, Tetrahymena sp., Epistylis sp., monogeneans, C. formosanus, and Dermocystidium sp.) is related to a predisposing factor, such as stress, low water quality, temperature, life stage, or contact with other animals. In addition, these parasites are easily avoidable with preventive practices. The parasitic presence in all analyzed fish species was due to a lack of sanitary control and biosecurity, and an absence of good management practices as a whole at the farm. Signs of these low water quality and poor biosecurity conditions were detected during technical visits at the farm (no water supply treatment, lack of a fallowing routine, absence of mechanical aerators and water quality testing routines, improper feeding, and close contact with birds and snails). Furthermore, there is little research on some of these parasites and their presence in Brazil, such as Dermocystidium sp. and C. formosanus. More studies are needed to understand the endemic parasitic fauna of the region and the farms, consequently, have better prevention methods and an increase in fish farms production and productivity. With regards to $C$. formosanus, it is necessary to conduct more epidemiologic studies on human infection in Brazil. 


\section{Acknowledgements}

The authors thank Coordination Office for Improvement of Higher-Education Personnel (CAPES) for sabbatical fellowship to P.H.M. Cardoso (CAPES 1808006) and National Council of Scientific and Technological Development (CNPq) for grant to M.L. Martins (CNPq 306635/2018-6). This study was funded in part by CAPES, under finance code 001.

\section{References}

Angel D, Jokumsen A, Lembo G. Aquaculture production systems and environmental interactions. In: Lembo G, Mente E, editors. Organic aquaculture: impacts and future developments. Cham: Springer; 2019. p. 103-118. http://dx.doi.org/10.1007/978-3-03005603-2_6.

Antonelli L, Foata J, Quilichini Y, Marchand B. Influence of season and site location on European cultured sea bass parasites in Corsican fish farms using indicator species analysis (IndVal). Parasitol Res 2016; 115(2): 561-568. http://dx.doi.org/10.1007/ s00436-015-4772-9. PMid:26446088.

Baia RRJ, Santos GG, Silva AS, Sousa BO, Tavares-Dias M. Parasite fauna of tambaqui reared in net-cages at two stocking densities. Bol Inst Pesca 2019; 45(3): e492. http://dx.doi.org/10.20950/1678-2305.2019.45.3.492.

Baptista C, Dellova D, Donati G, Cezário G, Real JV, Lino J, et al. Anuário brasileiro da piscicultura Peixe BR 2018 [online]. São Paulo: Associação Brasileira da Piscicultura; 2018 [cited 2020 Feb 17]. Available from: https://www.peixebr.com.br/anuario-2020/

Benovics M, Desdevises Y, Vukic J, Sanda R, Simková A. The phylogenetic relationships and species richness of host-specific Dactylogyrus parasites shaped by the biogeography of Balkan cyprinids. Sci Rep 2018; 8(1): 13006. http://dx.doi.org/10.1038/ s41598-018-31382-w. PMid:30158640.

Carvalho A, Lopes AL, Dellova D, França D, Dias I, Real JV, et al. Anuário brasileiro da piscicultura Peixe BR 2020 [online]. São Paulo: Associação Brasileira da Piscicultura; 2020 [cited 2020 Feb 17]. Available from: https://www.peixebr.com.br/anuario-2020/

Carvalho OS. Ocorrência de um Tiarídeo (mollusca) no Lago da Pampulha Belo Horizonte, MG, Brasil. Rev Soc Bras Med Trop 1986; 19(1): 57. http://dx.doi.org/10.1590/S0037-86821986000100012. PMid:3685527.

Chai JY, Jung BK. Fishborne zoonotic heterophyid infections: an update. Food Waterborne Parasito/ 2017; 8-9: 33-63. http://dx.doi. org/10.1016/j.fawpar.2017.09.001. PMid:32095640.

Chai JY, Sohn WM, Yong TS, Eom KS, Min DY, Lee MY, et al. Centrocestus formosanus (Heterophyidae): human infections and infection source in Lao PDR. J Parasitol 2013; 99(3): 531-536. http://dx.doi.org/10.1645/12-37.1. PMid:23116489.

Chen X, Wang B, Nie J, You P. A survey of gyrodactylid parasites on the fins of Homatula variegata in central China. PLoS One 2020; 15(3): e0230320. http://dx.doi.org/10.1371/journal.pone.0230320. PMid:32187220.

De NV, Le TH. Human infections of fish-borne trematodes in Vietnam: prevalence and molecular specific identification at an endemic commune in Nan Dinh province. Exp Parasitol 2011; 129(4): 355-361. http://dx.doi.org/10.1016/j.exppara.2011.09.005. PMid:21959023.

Eiras JC, Silva-Souza ATA. Dermocystidium infection in Trichomycterus sp. (Osteichthyes, Trichomycteridae). Parasite 2000; 7(4): 323-326. http://dx.doi.org/10.1051/parasite/2000074323. PMid:11147041.

Eiras JC, Takemoto RM, Pavanelli GC, Luque JL. Checklist of protozoan parasites of fishes from Brazil. Zootaxa 2012; 3221(1): 1-25. http://dx.doi.org/10.11646/zootaxa.3221.1.1.

El-Sayed, AFM. Tilapia culture. King's Lynn: CABI; 2006. http://dx.doi.org/10.1079/9780851990149.0000.

Ferguson HW, Hicks BD, Lynn DH, Ostland VE, BaileyJ. Cranial ulceration in Atlantic salmon Salmo salar associated with Tetrahymena sp. Dis Aquat Organ 1986; 2: 191-195. http://dx.doi.org/10.3354/dao002191.

Food and Agriculture Organization of The United Nations - FAO. The state of world fisheries and aquaculture: meeting the sustainable development goals [online]. Rome: FAO; 2018 [cited 2020 Feb 17]. Available from: http://www.fao.org/3/l9540EN/i9540en.pdf

Fujimoto RY, Couto MVS, Sousa NC, Diniz DG, Diniz JAP, Madi RR, et al. Dermocystidium sp. infection in farmed hybrid fish Colossoma macropomum x Piaractus brachypomus in Brazil. J Fish Dis 2018; 41(3): 565-568. http://dx.doi.org/10.1111/jfd.12761. PMid:29239008.

Ghiraldelli L, Martins ML, Jerônimo GT, Yamashita MM, Adamante WB. Ectoparasites communities from Oreochromis niloticus cultivated in the state of Santa Catarina, Brazil. Su Ürün Derg 2006; 1(2): 181-190. http://dx.doi.org/10.3923/jfas.2006.181.190.

Grigório MKRD. Diversidade parasitária e relação parasito-hospedeiro em Colossoma macropomum e seu híbrido tambatinga cultivados em Macapá, estado do Amapá [dissertation]. Macapá: Universidade Federal do Amapá; 2013. 
Hereford DM, Conway CM, Burdick SM, Elliott DG, Perry TM, Dolan-Caret A, et al. Assessing causes of mortality for endangered juvenile lost river suckers (Deltistes luxatus) in mesocosms in Upper Klamath Lake, South-Central Oregon, 2016. Reston: U.S. Geological Survey; 2019. http://dx.doi.org/10.3133/ofr20191006.

Jerônimo GT, Franceschini L, Zago AC, Silva RJ, de Pádua SB, Ventura AS, et al. Parasitos de peixes Characiformes e seus híbridos cultivados no Brasil. In: Tavares-Dias M, Mariano WS, editors. Aquicultura no Brasil: novas perspectivas. Aspectos biológicos, fisiológicos e sanitários de organismos aquáticos. São Carlos: Pedro \& João Editores; 2015. (vol. 1).

Jerônimo GT, Tavares-Dias M, Martins ML, Ishikawa MM. Manual para coleta de parasitos em peixes de cultivo. Brasília: Embrapa; 2012.

Klinger RE, Floyd RF. Introduction to freshwater fish parasites [online]. 2nd ed. Florida: Institute of Food and Agricultural Sciences, University of Florida; 2013 [cited 2020 Apr 24]. Available from: https://fisheries.tamu.edu/files/2013/09/Introduction-to-FreshwaterFish-Parasites.pdf

Kohn A, Cohen SC. South America Monogenea - list of species, hosts and geographical distribution. Int J Parasitol 1998; 28(10): 1517-1554. http://dx.doi.org/10.1016/S0020-7519(98)00083-6. PMid:9801914.

Lacerda ACF, Roumbedakis K, Bereta JGSJr, Nuñer APO, Petrucio MM, Martins ML. Fish parasites as indicators of organic pollution in southern Brazil. J Helmintho/ 2018; 92(3): 322-331. http://dx.doi.org/10.1017/S0022149X17000414. PMid:28566098.

Leibowitz MP, Santos NRV, Tavares GC, Assis GBN, Dorella FA, Figueiredo HCP, et al. Severe outbreak of Centrocestus formosanus (Trematoda: Heterophyidae) in farm-raised ornamental platies Xiphophorus maculatus. Dis Aquat Organ 2019; 134(2): 107-111. http://dx.doi.org/10.3354/dao03361. PMid:31043578.

Maciel PO, Garcia F, Chagas EC, Fujimoto RY, Tavares-Dias M. Trichodinidae in commercial fish in South America. Rev Fish Biol Fish 2018; 28(1): 33-56. http://dx.doi.org/10.1007/s11160-017-9490-1.

Mahboub $\mathrm{HH}$, Shaheen A. Prevalence, diagnosis and experimental challenge of Dermocystidium sp. infection in Nile tilapia (Oreochromis niloticus) in Egypt. Aquaculture 2020; 516: 734556. http://dx.doi.org/10.1016/j.aquaculture.2019.734556.

Martins ML, Cardoso L, Marchiori N, Pádua SB. Protozoan infections in farmed fish from Brazil: diagnosis and pathogenesis. Braz J Vet Parasitol 2015; 24(1): 1-20. http://dx.doi.org/10.1590/S1984-29612015013. PMid:25909248.

Mendoza L, Taylor JW, Ajello L. The class Mesomycetozoea: a heterogeneous group of microorganisms at the animal-fungal boundary. Annu Rev Microbio/ 2002; 56(1): 315-344. http://dx.doi.org/10.1146/annurev.micro.56.012302.160950. PMid:12142489.

Mumford S, Heidel J, Smith C, Morrison J, MacConnell B, Blazer V. Fish histology and histopathology [online]. 4th ed. Shepherdstown: USFWS-NCTC; 2007 [cited 2020 ]une 5]. Available from: https://nctc.fws.gov/resources/course-resources/fish-histology/index.html

Noga EJ. Fish disease: diagnosis and treatment. 2nd ed. Singapore: Wiley-Blackwell; 2010. http://dx.doi.org/10.1002/9781118786758.

Pádua SB, Martins ML, Valladão GMR, Utz L, Zara FJ, Ishikawa MM, et al. Host-parasite relationship during Epistylis sp. (Ciliophora: Epistylididae) infestation in farmed cichlid and pimelodid fish. Pesq Agropec Bras 2016; 51 (5): 520-526. http://dx.doi.org/10.1590/ S0100-204X2016000500012.

Pádua SB, Menezes RN Fo, Dias J No, Jerônimo GT, Ishikawa MM, Martins ML. Ictiofitiríase: conhecendo a doença para elaborar estratégias de controle. Panorama da Aquicultura 2012; 22(131): 22-31.

Pinto HA, Melo AL. Melanoides tuberculata (Mollusca: Thiaridae) as an intermediate host of Centrocestus formosanus (Trematoda: Heterophyidae) in Brazil. Rev Inst Med Trop São Paulo 2010; 52(4): 207-210. http://dx.doi.org/10.1590/S0036-46652010000400008. PMid:21748229.

Prosser RS, Lynn DH, Salerno J, Bennett J, Gillis PL. The facultatively parasitic ciliated protozoan, Tetrahymena glochidiophila (Lynn, 2018), causes a reduction in viability of freshwater mussel glochidia. J Invertebr Pathol 2018; 157: 25-31. http://dx.doi. org/10.1016/j.jip.2018.07.012. PMid:30076869.

Rataj M, Vdacny P. Multi-gene phylogeny of Tetrahymena refreshed with three new histophagous species invading freshwater planarians. Parasitol Res 2020; 119(5): 1523-1545. http://dx.doi.org/10.1007/s00436-020-06628-0. PMid:32152714.

Restiannasab A, Hemmatzadeh M, Khara H, Saljoghi ZS. Changes of haematological indices of grass carp, Ceteopharyngodon idella exposed to monogenean parasites, Gyrodactylus spp. and Dactylogyrus spp.J Parasit Dis 2016; 40(3): 627-629. http://dx.doi. org/10.1007/s12639-014-0547-y. PMid:27605756.

Roubach R, Gomes LC, Fonseca FAL, Val AL. Eugenol as an efficacious anaesthetic for tambaqui, Colossoma macropomum (Cuvier). Aquacult Res 2005; 36(11): 1056-1061. http://dx.doi.org/10.1111/j.1365-2109.2005.01319.x.

Rózsa L, Reiczigel J, Majoros G. Quantifying parasites in samples of hosts. J Parasitol 2000; 86(2): 228-232. http://dx.doi. org/10.1645/0022-3395(2000)086[0228:QPISOH]2.0.CO;2. PMid:10780537.

Scholz T, Salgado-Maldonado G. The introduction and dispersal of Centrocestus formosanus (Nishigori, 1924) (Digenea: Heterophyidae) in Mexico: a review. Am Midl Nat 2000; 143(1): 185-200. http://dx.doi.org/10.1674/0003-0031(2000)143[0185:TI ADOC]2.0.CO;2. 
Schulter EP, Vieira JER Fo. Evolução da piscicultura no Brasil: diagnóstico e desenvolvimento da cadeia produtiva de tilápia [online]. Rio de Janeiro: Ipea; 2017 [cited 2020 Feb 17]. Available from: http://repositorio.ipea.gov.br/bitstream/11058/8043/1/td_2328.pdf

Steckert LD, Cardoso L, Tancredo KR, Martins ML, Jerônimo GT. Dermocystidium sp. in the gills of farmed Oreochromis niloticus in Brazil. An Acad Bras Cienc 2019; 91(3): e20180959. http://dx.doi.org/10.1590/0001-3765201920180959. PMid:31553369.

Sumuduni BGD, Munasinghe DHN, Arulkanthan A. Chronological analysis of the damages caused by the metacercariae of Centrocestus formosanus in the gills of Cyprinus carpio and lesions caused by the adult flukes in Ardeola ralloides: an experimental study. Int J Vet Sci Med 2018; 6(2): 165-171. http://dx.doi.org/10.1016/j.ijvsm.2018.08.006. PMid:30564591.

Sumuduni BGD, Munasinghe DHN, Arulkanthan A. Survivability and Transmission rate of Centrocestus sp. Cercariae larvae to early fingerlings of Koi carp (Cyprinus carpio) and Lethal number of parasites to fry stage with site preference of infection. J Fish Life Sci 2017; 2(2): 35-39.

Valladão GMR, Alves LO, Pilarski F. Trichodiniasis in Nile tilapia hatcheries: diagnosis, parasite: host-stage relationship and treatment. Aquaculture 2016; 451: 444-450. http://dx.doi.org/10.1016/j.aquaculture.2015.09.030.

Vaz JF, Teles HMS, Correa MA, Leite SPS. Occurrence of Thiara (Melanoides) tuberculata (O.F. Mullher, 1774) (Gastropoda, Prosobranchia) in Brazil, first intermediate host of Clonorchis sinensis (Cobbold, 1875) (Trematoda, Plathyhelmintes). Rev Saude Publica 1986; 20(4): 318-322. http://dx.doi.org/10.1590/S0034-89101986000400008. PMid:3554478.

Wang Q, Yu Y, Zhang X, Xu Z. Immune responses of fish to Ichthyophthirius multifiliis (Ich): a model for understanding immunity against protozoan parasites. Dev Comp Immunol 2019; 93: 93-102. http://dx.doi.org/10.1016/j.dci.2019.01.002. PMid:30630003.

Woo PTK. Fish diseases and disorders: protozoan and metazoan infections. 2nd ed. King's Lynn: CABI; 2006. (vol. 1). http://dx.doi. org/10.1079/9780851990156.0000.

World Organisation for Animal Health - OIE. Aquatic Animal Health Code [online]. 22nd ed. Paris: OlE; 2019 [cited 2020 June 7]. Available from: https://www.oie.int/en/standard-setting/aquatic-code/

Zhang Q, Wang Z. Dermocystidium sp. infection in cultured juvenile southern catfish Silurus meridionalis in China. Dis Aquat Organ 2005; 65(3): 245-250. http://dx.doi.org/10.3354/dao065245. PMid:16119893. 